\title{
The influence of carbon-containing greenhouse gases on the dynamics of radial increment of Pinus cembra and Picea abies in the conditions of the Gorgany Nature Reserve
}

\author{
O. I. Moroz, O. N. Kuz, M. V. Ruda \\ Lviv Polytechnic National University, Lviv, Ukraine
}

Article info

Received 17.04.2020

Received in revised form 11.05.2020

Accepted 12.05.2020

Lviv Polytechnic

National University,

S. Banderyst., 12

Lviv, 79013, Ukraine

Tel.: +38-097-588-69-84

E-mail:

olyakuzon@gmail.com

\begin{abstract}
Moroz, O. I., Kuz, O. N., \& Ruda, M. V. (2020). The influence of carbon-containing greenhouse gases on the dynamics of radial increment of Pinus cembra and Picea abies in the conditions of the Gorgany Nature Reserve. Regulatory Mechanisms in Biosystems, 11(2), 283-289. doi:10.15421/022042
\end{abstract}

Based on the tree-ring chronology, we studied the radial increment of Swiss stone pine (Pinus cembra L.) and common spruce, or Norway spruce (Picea abies L.) as indicators of dendrochronological studies and, based on tree-ring chronology, reconstructed the annual changes of stem biomass and the amount of carbon accumulated in it by P. cembra and P. abies in the Gorgany Nature Reserve. Swiss stone pine stands are of great zoological importance as biotopes of nutcracker (Nucifraga caryocatactes L.), crossbill (Loxia curvirostra L.), capercaillie (Tetrao urogallus L.) and other representatives of rare boreal fauna. Samples were taken from trees of the Playa forest district of the Brusturyan Forest Hunting Range State Enterprise of the Transcarpathian Regional Forestry Administration (P. cembra and P. abies) from trees that did not have visual signs of damage in the Gorgany Nature Reserve. By cross-dating the radial increments of two radii for each tree, individual chronological series were drawn up. Carbon sequestration in $P$. cembra and $P$. abies stem wood was evaluated on the basis of dendrochronological analysis of radial increment. The accuracy of cross-dating of dendrochronological series of individual trees, individual chronological series, and representativeness of the generalized series were verified by conventional methods. It was found that the average annual radial increment of the trees under study is $11.48 \mathrm{~mm}$ in $P$. cembra and 14.39 in $P$. abies, and varies in the range of $1.86-5.49 \mathrm{~mm}$. The data obtained indicate an increase in the ability of $P$. cembra and $P$. abies to accumulate carbon with increasing age. The study of carbon sequestration in the stem wood of $P$. cembra and $P$. abies, based on dendrochronological analysis, made it possible to reconstruct the annual variation in stem biomass increment and accumulated carbon. The analysis of interdependence of the radial increment of $P$. cembra and $P$. abies in the Gorgany Nature Reserve and the value of carbon-containing greenhouse gases in the atmosphere, carried out by the augmented data sample, made it possible to specify the periods most significant for the formation of annual rings. The reaction in radial increment is most pronounced from June to September, with the annual values of carbon-containing greenhouse gases being maximally reflected in radial increment for the period from October to April.

Keywords: cores; dendrochronological analysis; phytomass; radial growth; greenhouse gases.

\section{Introduction}

Forests are an important component of the terrestrial carbon cycle, and forest vegetation, holding about $80 \%$ of carbon, is the main carbon sink of the planet (Dixon et al., 1994). The main resource of accumulated carbon in forests is the biomass of trees, mainly their stem part, as well as dead organic matter, litter and soil. Assessment of carbon sequestration by forest ecosystems is carried out mainly by indirect methods based on forest cadastre materials, since direct methods are quite complex and costly. Common indirect methods include the use of various models or equations of biomass and the conversion of the volume of wood stock into organic mass or carbon mass using conversion factors (Brown, 2002; Somogyi et al., 2007). Most studies on phytomass in Ukraine are carried out according to the method of Lakyda (2002), which involves the laying out of temporary trial plots. The purpose of the work is to study the radial increment of Swiss stone pine (P. cembra) and common spruce, or Norway spruce (P. abies) as indicators of dendrochronological studies and, based on tree-ring chronology, reconstruct the annual changes of stem biomass and the amount of carbon accumulated in it by P. cembra and $P$. abies under conditions of the Gorgany Nature Reserve. Swiss stone pine (P. cembra) is a relict of the early Holocene, being found in the Ukrainian Carpathians in 135 localities with an area of 4.2 thousand hectares. This is a coniferous tree with 5 needles to a cluster, averaging 20-25 $\mathrm{m}$ in height, and which may attain an age of 400 years or more. In the Gorgany Nature Reserve, 2,300 (Chernevyi et al., 2011) Swiss stone pine trees have been recorded. Some individual trees that grow on stony soil (detritus) of southern exposure can be found in Dovbushanka at the elevation of 1,730 m above sea level. Spruce-Swiss stone pine and Swiss stone pine-spruce forests in the reserve are distributed within the altitudes of 965-1,580 m a.s.l. and grow, mostly, on the steep slopes of the southern exposures, where they form Swiss stone pine-dominated stands. Primeval forest coenoses of the Pineto (cembrae) - Piceetum (abietis) subformation, which are formed on poor rocky soils covered with a peaty layer of organic litter, are distributed over an area of 539 ha in the reserve. Pineta cembrae forests are represented by the associations Piceeto (abietis) - Pinetum (cembrae) sphagnosum, Piceeto (abietis) - Pinetum (cembrae) vaccinoso (myrtilli) - hylocomiosum, Piceeto (abietis) - Pinetum (cembrae) vaccinoso (myrtilli) - sphagnosum. They are found sporadically in the upper (1,100-1,535 m above sea level) parts, mainly on the southern and southwestern slopes on cobble-stony brown soils. The phytocoenoses are listed in the Green Book of Ukraine (Didukh, 2009). Ecosystems with primeval Swiss stone pines are protected as relict forests. Swiss stone pine stands are of great zoological importance as biotopes of nutcracker (Nucifraga caryocatactes L.), crossbill (Loxia curvirostra L.), capercaillie (Tetrao 
urogallus L.) and other representatives of rare boreal fauna (Holubchak, 2019). Swiss stone pine supports the tree line and is suitable for afforestation of stony placers - gregots (Tretyak \& Chernevyy, 2018).

The Gorgany Nature Reserve is a nature conservation and research institution. Its main tasks are the protection and preservation of natural complexes and objects, conducting research and environmental health monitoring, elaboration of environmental recommendations, and disseminating environmental knowledge. Its most important goal is to preserve unique primeval forests, in particular those where Swiss stone pine (P. cembra) is involved. The Gorgany occupies the central part of the Ukrainian Carpathians and is a hard-to-reach place due to very steep slopes and rocky places. The reserve covers the slopes of the mountains from $710 \mathrm{~m}$ a.s.l. up to the ridges: Dovbushanka (1,754.6 $\mathrm{m}$ above sea level), Vedmezhyk (1,736 m), Polensky (1,693.6 m), Pikun (1,651 m), Kozii Gorgan (1,616 m), Skalky Verkhni (1,597 m), Babyn Pogar (1,478 m), Skalky Nyzhni $(1,300 \mathrm{~m})$ extending from the northwest to the southeast. They are characterized by steep asymmetric slopes and sharp mountain ridges; on the tops - stony talus (the local name is "gorgany"). The Dovbushansky massif is characterized by elongated ridges, peaks are with steeply descending northeastern and more gentle southwestern slopes.

The territory of the Gorgany Nature Reserve belongs to the Skyby zone of the Carpathians. Quaternary, Neogene, Paleogene and Upper Cretaceous deposits make up the geological, alluvial-deluvial loams, clays, sandy loam of the lithological structure of the Gorgany. The mountainous part of the reserve is composed of the Carpathian flysch consisting of conglomerates, sandstones, clay and marl shales of the Cretaceous and Quaternary periods. There are more than 500 different species of living organisms here which are closely associated with various tree species and were able to survive only thanks to the parent rock. The terrain of the territory is genetically and historically very diverse and represents the movement of an ancient glacier.

The climate of the forest district is that of the cold zone. The altitude is $1,360-1,400 \mathrm{~m}$ a.s.l., the azimuth of the slope is 2450 , the steepness of the slope is $35-360$, the topography is flat. The average temperature is $3.6^{\circ} \mathrm{C}$; average humidity $-90.8 \%$; the average amount of precipitation is $1,153 \mathrm{~mm}$. The herbaceous cover is dominated by: bilberry (Vaccinium myrtillus L.), cowberry (Vaccinium vitis-idea L.), and mosses of the genus Hylocomium (Bruch et al.) and Pleurozium (Brid.) Mitt. Spruce-dominant forests $(P$. abies $)$ occupy the largest tracts of the reserve $-89.1 \%$. Forest stands of mountain pine (Pinus mugo var. pumilio) - 7.3\%, Swiss stone pine (P. cembra) - 1.8\%, silver fir (Abies alba Mill.), beech (Fagus sylvatica L.) and other species cover $1.8 \%$ of the forested area. The most common are spruce-fir (2,377.9 ha) and beech-fir-spruce (1,196.3 ha) forest stands. A clear alternation of forests depending on altitudes, climatic, and soil-hydrological conditions characterizes 17 different types of forests, which are a kind of standard and reference, and the types of growth conditions are a reserve of almost unchanged natural and territorial complexes of the Ukrainian Carpathians (Klimchuk et al., 2006). The highest beech, fir and spruce trees in the Ukrainian Carpathians are recorded here. The largest trees of spruce, beech and fir in primeval forests attain a height of $53 \mathrm{~m}$ and a diameter of more than $160 \mathrm{~cm}$, Swiss stone pine $-34 \mathrm{~m}$ in height and $108 \mathrm{~cm}$ in diameter.

Old-growth Swiss stone pine-spruce and spruce-Swiss stone pine forests, along with fragments of the primary birch stands, give way in the subalpine zone to thickets of green alder (Duschekia viridis (Chaix.) Opiz.) and mountain pine (P. mugo) in the origins of streams on the sandstone placers of the Yemneny, demonstrating a 12.5-10.0 millennium history of forest emergence and development.

\section{Materials and methods}

Samples were taken from 20 trees of the Playa forest district of the Brusturyan Forest Hunting Range State Enterprise of the Transcarpathian Regional Forestry Administration (P. cembra - 14 pcs. and P. abies 6 pcs.) from trees that did not have visual signs of damage and which grow within compartment 5, plot 29 - trial area No. 5 of the Gorgany Nature Reserve. The height and diameter of each tree were measured at a height of $1.3 \mathrm{~m}$ above ground. At least two increment cores of wood were extracted from a tree at a height of $1.3 \mathrm{~m}$ in the spring of 2019 , the Presler- and Haglof (Sweden) increment borers being used.

The previously prepared cores were scanned by an Epson V33 tablet scanner with a resolution of 3,200 dpi. The width of the annular rings was measured by the "AxioVision (Carl Zeiss)" software with an accuracy of $0.01 \mathrm{~mm}$. The presence of false rings was established under the MBS-1 microscope. By cross-dating the radial increments of two radii for each tree, individual chronological series were drawn up. The quailty of dating and the calculation of standard statistical parameters were assessed using the COFECHA (Grissino-Mayer, 2001).

62 cores were extracted from 20 trees of $P$. cembra and $P$. abies, containing 7,405 annual rings formed during the period from 1822 to 2019. The minimum cambial age of the investigated trees in 2019 was 57 years, the maximum one was 94 years, the measured trunk diameter outside bark at a height of $1.3 \mathrm{~m}\left(\mathrm{D}_{1.3}\right)$ was $31.8-74.2 \mathrm{~cm}$.

Carbon sequestration in $P$. cembra and $P$. abies stem wood was evaluated on the basis of dendrochronological analysis of radial increment and data on forest management fieldwork in the Gorgany Nature Reserve. Based on the measured diameters in 2019, taking into account the bark thickness for young trees of $\sim 1.5 \mathrm{~cm}$ and the annual radial increment, the cumulative increment for each tree was calculated and the chronology of the cross-sectional area was determined. According to the materials of the forest inventory conducted in the reserve in 1958, 1979, 2000, 2004, 2013, the relationship between the height and age of $P$. cembra and $P$. abies was established, and the annual height increment was calculated using the equation (Tsuryk, 2006):

$$
H_{i}=\left\{\begin{array}{ll}
-0.0042 A_{i}^{2}+0.7161 A_{i}-4.4692, & A_{i} \leq 85.25 ; \\
26.05 . & A_{i}>85.25,
\end{array} \Delta H_{i}=H_{i}-H_{i-1},\right.
$$

where $H_{i}$ is the height of tree of $i$-th year, $\Delta H_{i}$ is the annual height increment, $A_{i}$ is the age of tree of $i$-th year.

The annual change in the volume of the trunk of each tree under study $\left(V_{i}\right)$ is calculated by the formula:

$$
\Delta V_{i}=\left(S_{i} \times H_{i}-S_{i-1} \times H_{i-1}\right),
$$

where $S_{i}$ is the cross-sectional area of the trunk of the $i$-th year; $H_{i}$ is the height of tree of $i$-th year.

The dry matter density for the stem of $P$. cembra and P. abies $575 \mathrm{~kg} / \mathrm{m}^{3}$ was used to calculate the phytomass of the trunk (Netsvetov \& Suslova, 2009), and to determine the mass of carbon deposited in it, a coefficient of 0.5 was used (Medlyn et al., 2001). The accuracy of crossdating of dendrochronological series of individual trees, individual chronological series, and representativeness of the generalized series were verified by conventional methods (Grissino-Mayer, 2001; Bunn, 2010).

We calculate the statistical indexes of radial increment of $P$. cembra and $P$. abies: average value $x=3.18$; standard error $\mathrm{SE}=0.203$; standard deviation $\mathrm{SD}=0.424$; the confidence interval for the mean value at $\mathrm{P}_{0.95}: 2.758 \leq \mathrm{x} \leq 3.606$; the coefficient of variation $\mathrm{V}_{\sigma}=27.7 \%$, since $\mathrm{V}_{\sigma}<33.0 \%$, then the sample is homogeneous; median $\mathrm{Me}=2.89$; asymmetry coefficient $\gamma_{1}=0.90$, high dextrality; coefficient of excess $\gamma_{2}=0.35$, peaked distribution.

We investigate the dependence of radial increment on the diameter of $P$. cembra and $P$. abies. To do this, we construct a regression equation using the least squares method:

$$
\mathrm{MRW}=27.681 D+34.806 \text {, }
$$

where $D$ is the diameter, MRW is radial increment.

Let us estimate the correlation density by calculating the Pearson correlation coefficient $r=0.968$, according to the Cheddock table, the correlation density of radial increment of the diameter is very high. Considering $\bar{r}^{2}=0.937$, then a radial increment is $93.7 \%$ dependent on the diameter and $6.3 \%$ on other factors. For the significance level $\alpha=$ 0.05 we check the null hypothesis $\mathrm{H}_{0}: \mathrm{r}=0$ according to the competing hypothesis $\mathrm{H}_{1}: \mathrm{r} \neq 0$. We calculate the empirical value of the criterion:

$$
T_{\text {emp }}=\bar{r} \frac{\sqrt{n-2}}{1-\bar{r}^{2}}=0.968 \frac{\sqrt{20-2}}{\sqrt{1-0.937}}=16.365 \text {. }
$$

For a given level of significance and the number of degrees of freedom $\mathrm{k}=20-2=18$ by using the table of critical points of Student's distribution we find that $t_{0.05}=2.10$. Since $T_{e m p}>t_{0.05}$, we reject the null hypothesis $\mathrm{H}_{0}$ and conclude that the sample correlation coefficient is 
significant and random variables are correlated. We calculate the confidence interval for the general correlation coefficient:

$$
\begin{aligned}
& \bar{r}-t_{k r} \frac{1-\bar{r}^{2}}{\sqrt{n}} \leq r \leq \bar{r}+t_{k r} \frac{1-\bar{r}^{2}}{\sqrt{n}} \\
& 0.968-0.0276 \leq r \leq 0.968+0.0276
\end{aligned}
$$

Let us investigate the dependence of radial increment on the number of annual rings in $P$. cembra and $P$. abies. To do this, we construct a regression equation using the least squares method:

$$
M R W=-0.0072 N+4.4071 \text {, }
$$

where $N$ is the number of annual rings.

Let us estimate the correlation density by calculating the Pearson correlation coefficient $r=0.138$, according to the Cheddock table, the correlation density is weak. Since $\mathrm{r}^{2}=0.019$, the radial increment is only $1.9 \%$ dependent on the number of annual rings. For the significance level $\alpha=$ 0.05 we check the null hypothesis $\mathrm{H}_{0}: \mathrm{r}=0$ according to the competing hypothesis $\mathrm{H}_{1}: \mathrm{r} \neq 0$. We calculate the empirical value of the criterion:

$$
T_{\text {emp }}=\bar{r} \frac{\sqrt{n-2}}{\sqrt{1-\bar{r}^{2}}}=0.138 \frac{\sqrt{20-2}}{\sqrt{1-0.019}}=0.591 .
$$

For a given level of significance and the number of degrees of freedom $\mathrm{k}=20-2=18$ according to the table of critical points of Student's distribution, we find that $t_{0.05}=2.10$. Since $T_{\text {emp }}>t_{0.05}$, then the null hypothesis $\mathrm{H}_{0}$ is confirmed, and we conclude: the sample correlation coefficient is negligible and the random variables are uncorrelated.

To analyze a long-term change in the fluctuations of phytomass increment and carbon mass increase in the atmosphere, the corresponding series were smoothed using 11-year fixed-window cubic smoothing in the ARSTAN program (Cook, E. R., \& Krusic, P. J. Programm ARSTAN (Ver. 41d), 2005. www.ldeo.columbia.edu/tree-ring-laboratory/resources/ software) and a correlation analysis of these series was made using standard radial increment chronology since it retains a significant proportion of low-frequency changes than others (Cook \& Kairiukstis, 1990).

\section{Results}

The average number of dated annual rings in the samples, that is, the length of individual series in terms of dendrochronology, was 153 years. The value of the average sensitivity, or relative variability of the ring width, is $0.209 \mathrm{~mm}$, which indicates that the growth conditions correspond to the environmental needs of $P$. cembra and $P$. abies at the study site. The average first-order autocorrelation, which reflects the influence of the previous year's conditions on the current increment, is 0.667 . This figure is relatively low, but is within the range typical for most pine stands. After standardization of individual series and their generalization, the signal-to-noise ratio of the combined chronology was 16.25 , which indicates the presence of a climatic signal in it, that is, the variability of climatic factors affects the variation in annual growth of P. cembra and P. abies in the study stands, which synchronize the growth of trees. The mean annual radial increment (MRW) is $3.18 \pm 0.88 \mathrm{~mm}$ and varies between 1.86-5.49 mm (Fig. 1).

The use of a moving average helps to determine changes in the representativeness of a sample or an expressed population signal (EPS in Fig. 2), which can be interpreted as a measure of the consistency of the generalized chronological series of the chronology with the entire coenopopulation from which model trees are selected. This figure exceeded the generally accepted critical value of 0.85 in 1855 , i.e., from this date, the sample obtained sufficiently reflects the studied coenopopulation of $P$. cembra and $P$. abies. An increase in the representativeness of the sample in an earlier period is possible provided that the number of individual series is increased. On average, the EPS indicator reaches 0.942 over the entire period under review. The average correlation curve between the series (RBar in Fig. 2) reflects fluctuations in the synchronization of the radial increment of individuals of the coenopopulation.

The accumulation of carbon in the stem wood of the investigated trees was determined based on the calculation of the annual increment in the cross-sectional area of the trunk. As of 2019, the smallest crosssectional area was $0.07 \mathrm{~m}^{2}$ at $\mathrm{D}_{1.3}$ outside bark of $31.8 \mathrm{~cm}$, the largest $0.41 \mathrm{~m}^{2}$ at $\mathrm{D}_{1.3}-74.2 \mathrm{~cm}$. In 2019 , the average carbon mass of the investigated trees of $P$. cembra and $P$. abies in the Gorgany Nature Reserve was $366 \pm 176 \mathrm{~kg}$ and varied between $167-922 \mathrm{~kg}$ depending on the $\mathrm{D}_{1.3}$ value (Fig. 3).

The annual carbon accumulation in the trunks of the trees under study has a growing trend with its average value reaching its maximum in the year 2007-2008 and 2016-2017 (11-12 kg/year). With age, $P$. cembra and $P$. abies increase the total mass of their stem wood as well as the mass of carbon deposited in it. At the age of 20, the investigated trees accumulated on average $2 \mathrm{~kg} /$ year, at 30 years $-5 \mathrm{~kg} /$ year, the maximum carbon sequestration at the age of $45-70$ years being $10 \mathrm{~kg} /$ year (Fig.4).

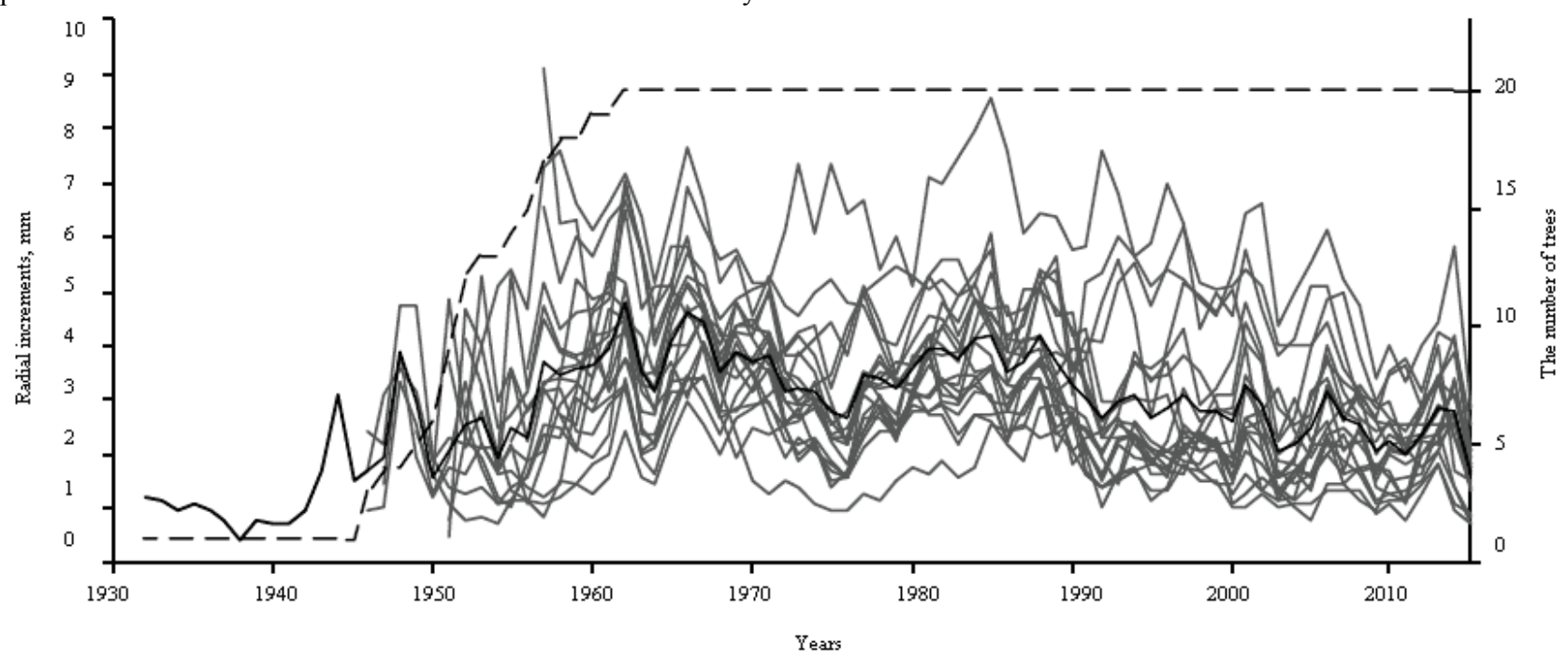

Fig. 1. Generalized chronology (black), individual series (grey) of radial increment and the number of trees (dotted) $P$. cembra and $P$. abies by the years

The correlation dendrocarbon analysis has proved that in the study area there is a slight cumulative negative effect of carbon-containing greenhouse gases on the increment of $P$. cembra and $P$. abies. The reaction in radial increment is most pronounced from June to September, with the annual values of carbon-containing greenhouse gases being maximally reflected in radial increment for the period from October to April.

Discussion
Old-growth forests, accumulating biomass for centuries, are able to accumulate carbon in much larger quantities than young or middle-aged stands (Carey et al., 2001; Luysseert et al., 2008). Thus, the estimated aboveground biomass of the protected old-growth broadleaved forest in the Ticino river valley, Italy, was 348 tha and, accordingly, 174 tha of carbon, of which $63 \%$ is European oak biomass (Granata, 2016; Brown, 2002). The stock of aboveground biomass of the 80 -year-old reserved 
beech-oak forest in Belgium amounted to $123 \mathrm{t}$ ha, and the accumulated carbon - 79 tha (Walle et al., 2001). A global assessment of the carbonsequestration function of forests has shown that forest vegetation and soil contain about $1.146 \times 10^{12}$ tons of carbon (Dixon et al., 1994; Politov et al., 2008). According to the State of Europe's Forests, forest biomass in Romania contains 616.36 million tons of carbon, 619.1 mil- lion tons in Belarus, 641 million tons in Italy, 822 million tons in Poland, 1.364 million tons in France (Pretzsch, 2009). The total phytomass of Ukraine's forests is $1,523.5$ million tons, in which about 757.9 million tons of carbon have been sequestered, of which 203.3 million tons have been sequestered by oak stands (Lakyda, 2002; Lakyda et al., 2013).
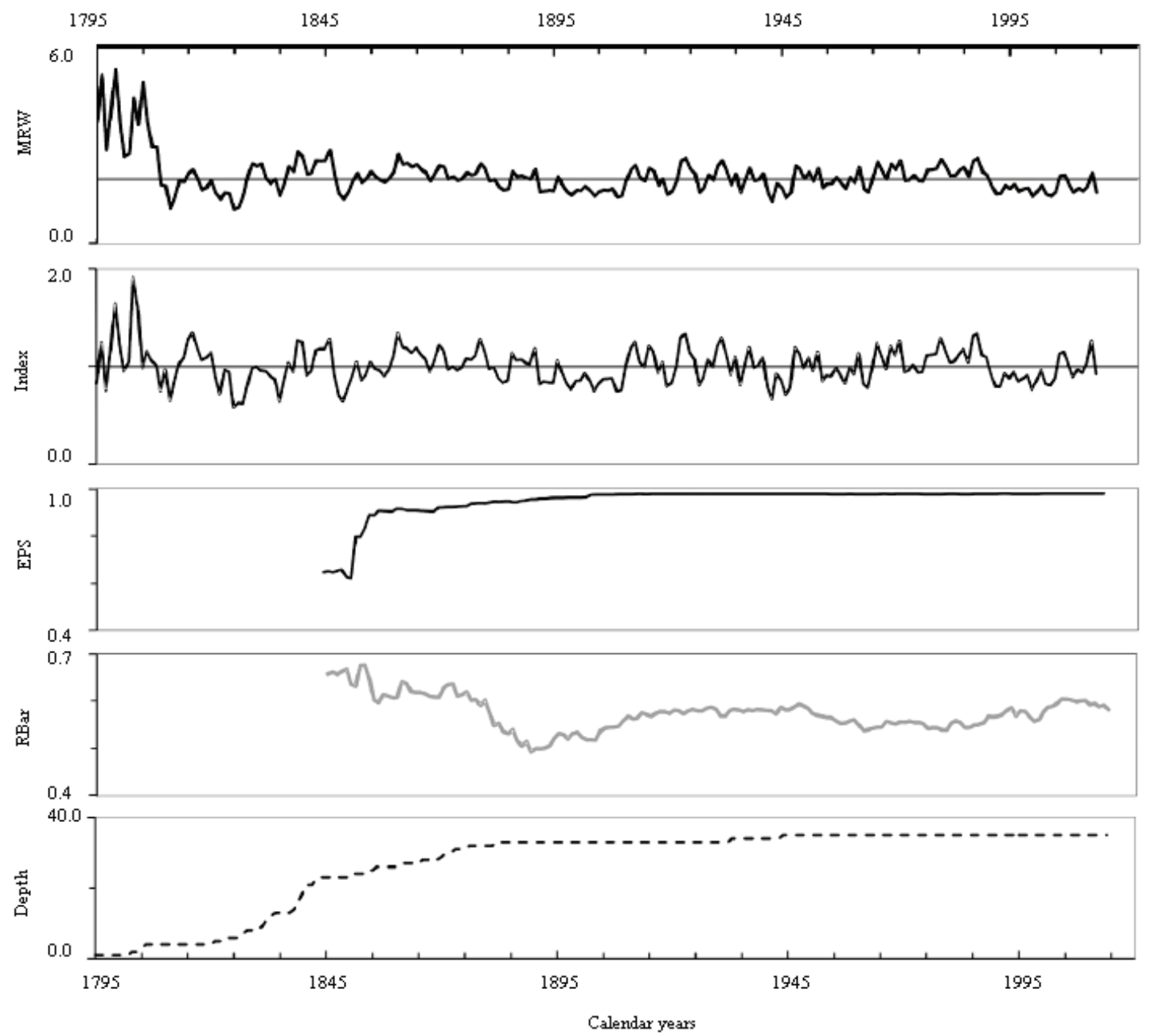

Fig. 2. Generalized chronological series of $P$. cembra and $P$. abies in the Gorgany Nature Reserve: mean annual increment (MRW), increment index (Index), expressed population signal (EPS), average correlation between series (RBar), number of trees (Depth)

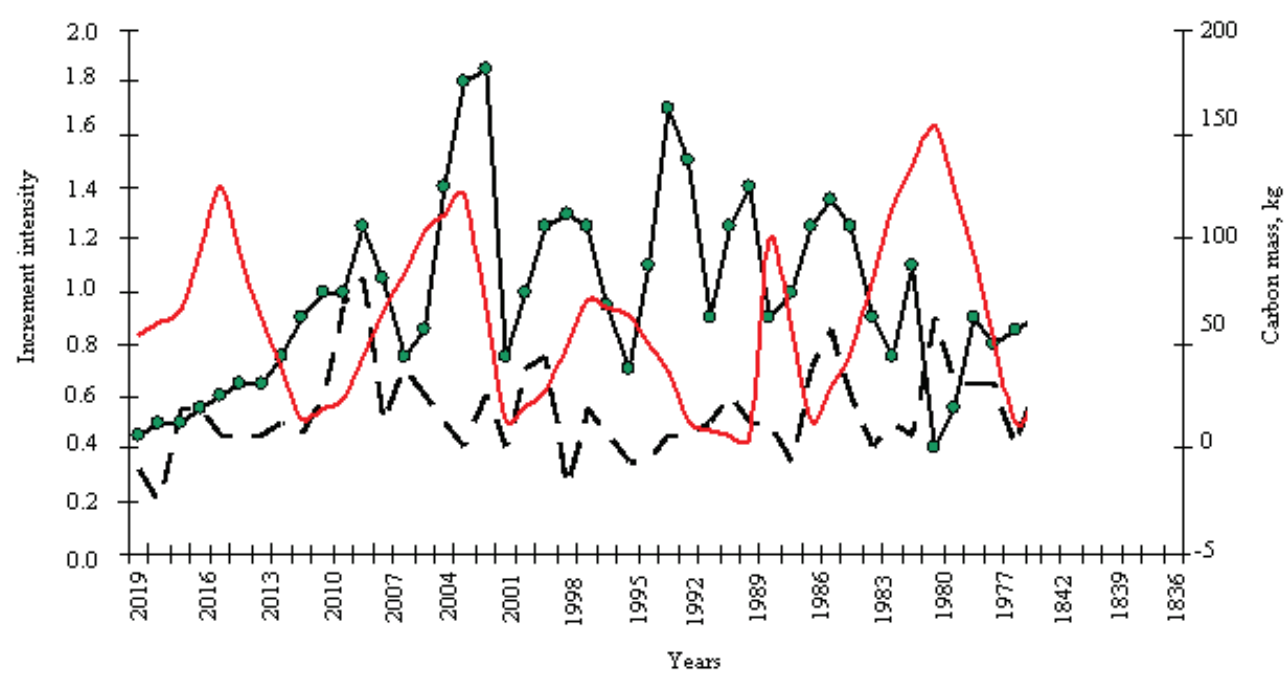

Fig. 3. Averaged masses of accumulated carbon (red line) in $P$. cembra (line with marker) and $P$. abies (dotted line) stem wood in the Gorgany Nature Reserve by years (fragment) 


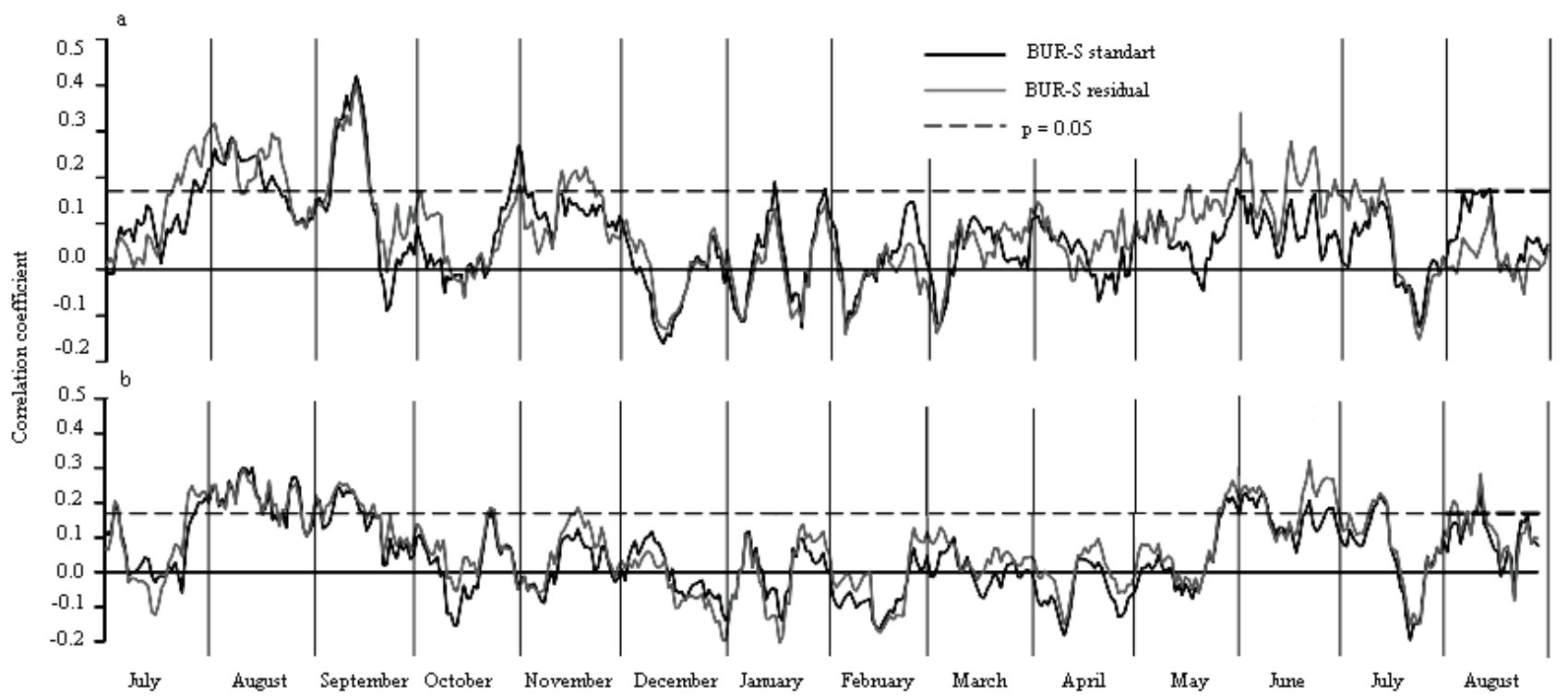

Months

Fig. 4. Correlation coefficients of carbon-containing greenhouse gases in the atmosphere with radial increment under conditions of the Gorgany Nature Reserve: $a-P$. cembra; $b-P$. abies; BUR-N radial increments and the monthly value of carbon-containing greenhouse gases; BUR-S radial increments and the annual value of carbon-containing greenhouse gases

Overall, the correlation between the individual series was 0.549 for the period under review, which is higher than the generally accepted minimum value of 0.40 (Grissino-Mayer, 2001) and, therefore, gives reason to consider the generalized series reliable. The average radial increment of these $P$. cembra and $P$. abies is $1.86 \mathrm{~mm}$, which is significantly less than the average for the entire sample. The tendency towards increasing the stem phytomass and carbon accumulated in it with age by $P$. cembra and $P$. abies is also confirmed by our previous studies. In forests aged 15 to 800 years, net ecosystem productivity (carbon balance) is usually positive (Tretyak \& Chernevyy, 2018; Tretyak et al., 2019). However, old trees, due to damage to the trunk and destruction of wood, not only bind carbon, but also emit it into the atmosphere, but the amount of carbon returned is difficult to estimate.

The carbon sequestration in the trunks of the investigated trees of P. cembra and P. abies during the period 1853-2019 is of uniformly increasing nature, closely related to the annual increase in cross-sectional area, height increment of a tree and a corresponding increase in the stem phytomass accumulation.

The analysis of interdependence of the radial increment of $P$. cembra and $P$. abies in the Gorgany Nature Reserve and the value of carbon-containing greenhouse gases in the atmosphere, carried out by the augmented data sample, made it possible to specify the periods most significant for the formation of annual rings. The main limiting factor for the value of carbon-containing greenhouse gases in atmosphere for the study region is July - August. To highlight the features of the physiological reactions of wood, it will be appropriate to simulate its formation taking into account abiotic factors at the cellular level using the Vaganov-Shashkin simulation model (Vaganov et al., 2011).

\section{Conclusions}

The study of carbon sequestration in the stem wood of $P$. cembra and $P$. abies, based on dendrochronological analysis, made it possible to reconstruct the annual variation in stem biomass increment and accumulated carbon. The analysis of interdependence of the radial increment of P. cembra and P. abies in the Gorgany Nature Reserve and the value of carbon-containing greenhouse gases in the atmosphere, carried out by the augmented data sample, made it possible to specify the periods most significant for the formation of annual rings. The reaction in radial increment is most pronounced from June to September, with the annual values of carbon-containing greenhouse gases being maximally reflected in radial increment for the period from October to April. The data obtained indicate an increase in the ability of $P$. cembra and $P$. abies to accumulate carbon with increasing age. The total mass of carbon in the trunk of trees of this age is $316 \mathrm{~kg}$, which is $1 / 5$ of the values of these age indicators (150 200 years) of trees. The processes of in-life decay of wood and carbon release in European oak and other forest-forming species require further study.

\section{References}

Brown, S. (2002). Measuring carbon in forests: Current status and future challenges. Environmental Pollution, 116, 363-372.

Bunn, A. G. (2010). Statistical and visual crossdating in R using the dplR library. Dendrochronologia, 28(4), 251-258.

Carey, E. V., Sala, A., Keane, R., \& Callaway, R. M. (2001). Are old forests underestimated as global carbon sinks? Global Change Biology, 7, 339-344.

Chernevyi, Y. I., Tretiak, P. R., \& Savchyn, A. I. (2011). Osoblyvosti rostu derev sosny kedrovoji (Pinus cembra L.) u verkhiv'ji basejnu riky Limnyci u Karpatakh [Growth characteristics of trees of the Swiss pine (Pinus cembra L.) in the upper basin of Limnytsia river in Carpathians]. Scientific Bulletin of Ukrainian National Forestry University, 21(11), 54-61 (in Ukrainian).

Cook, E. R., \& Kairiukstis, L. A. (1990). Methods of dendrochronology. Applications in the environmental sciences. Springer, Dordrecht.

Didukh, Y. P. (2009). Zelena knyha Ukrainy [Green Book of Ukraine]. Alterpres, Kyiv (in Ukrainian).

Dixon, R., Brown, S., Houghton, R., Solomon, A., Trexler, M., \& Wisniewski, J. (1994). Carbon pools and flux of global forest ecosystems. Science, 263, $185-190$.

Granata, M., Gratani, L., Bracco, F., Sartori, F., \& Catoni, R. (2016). Carbon stock estimation in an unmanaged old-growth forest: A case study from a broadleaf deciduous forest in the Northwest of Italy. International Forestry Review, 18(4), 444451.

Grissino-Mayer, H. D. (2001). Evaluating crossdating accuracy: A manual and tutorial for the computer program COFECHA. Tree-Ring Research, 57(2), 205-221.

Holubchak, O., Savchyn, A., Tretyak, P., \& Chernevyy, J. (2019). Dynamika przyrostu świerka Picea abies (L.) H. Karst i limby Pinus cembra (L.) w pobliżu gómej granicy lasu w Gorganach (Ukraina) [Growth dynamics of Picea abies (L.) H. Karst. and Pimus cembra (L.) near the upper timberline in the Gorgany range (Ukraine)]. Roczniki Bieszczadzkie, 27, 253-266 (in Polish).

Kassier, H. (2011). Forest dynamics, growth and yield: From measurement to model. Southern Forests: a Journal of Forest Science, 73(1), 63-65.

Klimuk, Y. V., Mitskevych, U. D., Yakushenko, D. M, Solomakha, V. A., Chornej, I. I., \& Budzhak, V. V. (2006). Pryrodnyj zapovidnyk "Gorgany". Roslynnyj svit [Gorgani Nature Reserve. Plants]. In: Solomakha, V. A. (Ed.). Pryrodno-zapovidni terytorii Ukrainy. Roslynnyi svit. Vol. 6. Fitosotsiotsentr, Kyiv (in Ukrainian).

Lakyda, P. I. (2002). Fitomasa lisiv Urainy [Phytomass of the forests of Ukraine]. Zbruch, Ternopil (in Ukrainian). 
Lakyda, P. I., Shvydenko, A. Z., Shchepashchenko, D. H., Vasylyshyn, R. D., Bilous, A. M., Lakyda, I. P., \& Matushevych, L. M. (2013). Biotychna produktyvnistj lisiv Ukrajiny v jevropejsjkomu ekoresursnomu vymiri [Biotic productivity of Ukrainian forests in the European ecoresource dimension]. Biological Resources and Nature Management, 5(5-6), 99-106.

Luyssaert, S., Schulze, E. D., Borner, A., Knohl, A., Hessenmoller, D., Law, B. E., Ciais, P., \& Grace, J. (2008). Old-growth forests as global carbon sinks. Nature, 455, 213-215.

Medlyn, B. E., Barton, C. V. M., Broadmeadow, M. S. J., Ceulemans, R., De Angelis, P., Forstreuter, M., Freeman, M., Jackson, S. B., Kellomäki, S., Laitat, E., Rey, A., Roberntz, P., Sigurdsson, B. D., Strassemeyer, J., Wang, K., Curtis, P. S., \& Jarvis, P. G. (2001). Stomatal conductance of forest species after long-term exposure to elevated $\mathrm{CO}_{2}$ concentration: A synthesis. New Phytologist, 149, 247-264

Netsvetov, M. V., \& Suslova, E. P. (2009). Mehanicheskaja ustojchivost' derev'ev i kustarnikov $\mathrm{k}$ vibracionnym zagruzkam [Mechanical resistance of trees and shrubs to vibration loads]. Promyshlennaia Botanika, 9, 60-67 (in Russian).

Politov, D. V., Pirko, Y. V., Pirko, N. N., Mudrik, E. A., \& Korshikov, I. I. (2008) Analiza sistemului de încru-ci are în douã populabii de Pinus cembra din Carpapii Ucrainieini. Annals of Forest Research, 51, 11-18.

Pretzsch, H. (2009). Forest dynamics, growth, and yield. In: Forest Dynamics, growth and yield. Springer, Berlin.
Somogyi, Z., Cienciala, E., Mäkipää, R., Muukkonen, P., Lehtonen, A., \& Weiss, P. (2007). Indirect methods of large-scale forest biomass estimation. European Journal of Forest Research, 126, 197-207.

Tretyak, P., \& Chernevyy, Y. (2018). The grow of trees of the Carpathian fores (in the basin of the Dniester River). Publishing House of Lviv Polytechnic National University, Lviv.

Tretyak, P., Pozynytch, I., Savytska, A., \& Boychuk, I. (2019). Forests with Swiss stone pine (Pinus cembra L.) in Gorgany range (Eastern Carpathians, Ukraine). In: Kannenberg, K., \& Szramki, H. (Eds.). Zarządzanie ochroną przyrody w lasach. Management of Environmental Protection in Forests, Tuchola.

Tsuryk, Y. I. (2006). Taksacija dereva ta jogho chastyn [Taxation of the tree and its parts]. Ukrainian National Forestry University, Lviv (in Ukrainian).

Vaganov, E. A., Anchukaitis, K. J., \& Evans, M. N. (2011). How well understood are the processes that create dendroclimatic records? A mechanistic model of the climatic control on conifer tree-ring growth dynamics. In: Hughes, M., Swetnam, T., \& Diaz, H. (Eds.). Dendroclimatology, developments in paleoenvironmental research. Springer, Dordrecht. Vol. 11. Pp. 37-76.

Walle, I., Mussch, S., Samson, R., Lust, N., \& Lemeur, R. (2001). The above and belowground carbon pools of two mixed deciduous forest stands located in East-Flanders (Belgium). Annals of Forest Science, 58, 507-517. 